\title{
Environmental stress, future climate, and germination of Myracrodruon urundeuva seeds ${ }^{1}$
}

\author{
Gilmara Moreira de Oliveira ${ }^{2}$, Fabricio Francisco Santos da Silva ${ }^{2}$, \\ Marcelo do Nascimento Araujo ${ }^{3}$, Danielle Carolina Campos da Costa ${ }^{4}$, \\ Samara Elizabeth Vieira Gomes ${ }^{4}$, Janete Rodrigues Matias ${ }^{5}$, Francislene Angelotti ${ }^{6}$, \\ Claudineia Regina Pelacani $\mathrm{Cruz}^{2}$, Charlotte E. Seal ${ }^{7}$, Bárbara França Dantas ${ }^{6 *}$
}

\begin{abstract}
Myracrodruon urundeuva, a native species from the Brazilian Caatinga, is widely distributed across its endemic region, where it also plays an essential socioeconomic role. The objective of this study was to evaluate the influence of environmental stress on the germination of M. urundeuva seeds harvested in different years (2010 to 2013). Seeds were germinated at constant temperatures between 10 to $40{ }^{\circ} \mathrm{C}$, osmotic potentials from 0 to $-0.8 \mathrm{MPa}$ (in polyethylene glycol 6000 solutions), and from 0 to $-0.5 \mathrm{MPa}$ (in $\mathrm{NaCl}$ solutions). The experiment was conducted according to a completely randomized design, with three replicates of 50 seeds, in a factorial scheme (harvest year x stress intensity) for each environmental stress. Germination data were then analysed using thermal, hydro and halo time models, and future germination responses projected according to climate change scenarios. The germination thermal thresholds ranged from 7.4 to $53.3{ }^{\circ} \mathrm{C}$. The germination base osmotic threshold (using polyethylene glycol) was $-0.6 \mathrm{MPa}$ and the base osmotic threshold in $\mathrm{NaCl}$ was $-0.43 \mathrm{MPa}$. Seeds from different harvest years showed distinct tolerance to environmental stresses. The thermal, hydro and halo-time models were efficient to describe the germinative response of seeds, and the climate models allowed to identify the germination responses of M. urundeuva in future climate. According to the models for future climate (RCP 8.5), the reduction of rainfall by 2100 will directly affect seed germination and seedling recruitment of $M$. urundeuva.
\end{abstract}

Index terms: Caatinga, forest seeds, osmotic potential, temperature.

\section{Estresses ambientais, clima futuro e germinação de sementes de Myracrodruon urundeuva}

\begin{abstract}
RESUMO - Myracrodruon urundeuva, espécie nativa da Caatinga e de ampla distribuição geográfica, apresenta relevante valor socioeconômico. Objetivou-se avaliar a influência de estresses ambientais sobre a germinação de lotes de diferentes safras de $M$. urundeuva. Foram testadas as temperaturas constantes de 10 a $40{ }^{\circ} \mathrm{C}$ e potenciais osmóticos de 0 a $-0,8 \mathrm{MPa}$ (usando-se polietileno glicol 6000) e de 0 a -0,5 MPa (usando-se soluções de $\mathrm{NaCl}$ ). $\mathrm{O}$ delineamento experimental foi inteiramente casualizado com três repetições de 50 sementes em esquema fatorial (safras x intensidade do estresse) para cada estresse abiótico. Os dados de germinação foram então analisados utilizando modelos de tempo térmico, hídrico, hálico (salino), projetando respostas de germinação em cenários climáticos futuros. Os limites térmicos para a germinação das sementes variaram entre 7,4 e $53,3{ }^{\circ} \mathrm{C}$. O limite osmótico base para germinação de sementes em polietileno glicol foi de -0,6 MPa e em NaCl foi de -0,43 MPa. Segundo modelos de cenários futuros de mudanças climáticas, a redução de semanas com precipitação mínima afetará diretamente a germinação de sementes e o recrutamento de plântulas de M. urundeuva. Assim, conclui-se que sementes de M. urundeuva foram tolerantes aos estresses abióticos. Os modelos de tempo térmico, hídrico e hálico foram eficientes para descrever a resposta foram eficientes para descrever a resposta germinativa de sementes, e os modelos climáticos permitiram identificar as respostas germinativas de M. urundeuva em cenários futuros de mudanças climáticas. De acordo com os modelos para clima futuro (RCP 8.5), a redução da precipitação até 2100 afetará diretamente a germinação de sementes e recrutamento de plântulas de M. urundeuva.
\end{abstract}

Termos para indexação: Caatinga, sementes florestais, potencial osmótico, temperatura.

${ }^{1}$ Submitted on 02/22/2018. Accepted for publication on 10/02/2018.

${ }^{2}$ Departamento de Biologia, Universidade Estadual de Feira de Santana, 44036-900 - Feira de Santana, BA, Brasil.

3Faculdade Uninassau, 56308-210 - Petrolina, PE, Brasil.

${ }^{4}$ Departamento de Tecnologia e Ciências Sociais, Universidade do Estado da Bahia, 48.900-000 - Juazeiro, BA, Brasil.
${ }^{5}$ Pró-Reitoria de Pesquisa e Pós-Graduação, Universidade Federal Rural do Semiárido, 59.625-900 - Mossoró, RN, Brasil.

${ }^{6}$ Embrapa Semiárido, LASESA, 56302-970 - Petrolina, PE, Brasil.

${ }^{7}$ Department of Comparative Plant and Fungal Biology, Royal Botanic Gardens Kew, Wakehurst, West Sussex, UK.

*Corresponding author <barbara.dantas@embrapa.br> 


\section{Introduction}

Climate projections published in the Fifth Assessment Report by the Intergovernmental Panel on Climate Change (IPCC) indicate increasing emission of greenhouse gases (GHG) as the primary cause for temperature changes. As an outcome, future climate scenarios include a increase of the average global temperature and a decrease in the precipitation levels (IPCC, 2014), which can alter the salinity of the soil (Knowles and Cayan, 2002; Gondim et al., 2010). In some areas more susceptible to the risks imposed by climate alterations, such as the Caatinga biome in Brazil's Northestern region, the aridity may be intensified, which might even lead to desertification (Marengo et al., 2016) and increased soil salinity.

Climate change may have important consequences to all stages of plant development, from seed germination to growth and establishment of species (Maraghni et al., 2010). Germination is an ecophysiological process fundamental to plant diversity (Bewley et al., 2013), which depends on the environmental conditions to which seeds are subjected to. Thus, the capacity of seeds for germinating in a broad variety of conditions assures the survival and regeneration of species (Vivian et al., 2008).

The knowledge of the environmental conditions which interfere in production and germination of seeds is fundamental. Temperature influences germination by affecting the speed of water imbibition, and also on biochemical and enzymatic reactions ruling the entire process (Flores et al., 2014). Changes in the environmental temperature may also affect the permeability of membranes (Maraghni et al., 2010). Thus, germination only occurs within certain species-specific temperature limits (Bewley et al., 2013).

The germinative process depends on the availability of water and its movement through the tissues surrounding the seed. In this sense, the excess of salt in the substrate affects the availability of water to seeds, by inhibiting or slowing down its absorption (Chaves et al., 2009). Besides, the buildup of $\mathrm{Na}^{+}$and $\mathrm{Cl}^{-}$ions causes ruptures in seed tegument layers and has a toxic effect, which might lead to the death of seeds (Freitas et al., 2013). In the field, such conditions are naturally induced by low precipitation levels, soil salinization, and high temperatures, phenomena that can compromise the germination, initial development, and recruitment of plants, even of those that are well-adapted to hot-dry climates.

Myracrodruon urundeuva Allemão (Anacardiaceae), known as aroeira-do-sertão, is a species widely spread throughout the Brazilian territory, which also plays an essential socioeconomic role. Its bark is rich in phenolic compounds with cicatrizing and anti-inflammatory properties (Carlini et al., 2010). Also, its wood has considerable mechanical resistance and does not putrefy easily, thus being largely used in construction and furniture. However, since its use is mostly connected to uncontrolled exploitation, its survival is critically under threat (CNCFlora, 2012).

Some studies have been conducted to better understand the germination behavior of $M$. urundeuva exposed to different environmental factors (Virgens et al., 2012; Guedes et al., 2011). However, there are no studies that predict germination in future climate scenarios, simultaneously considering seed lots obtained from different harvests, of varying physiological quality, and the response to alterations in temperature and water availability. This information is essential to appraise the adaptation capacity of this species (Seal et al., 2017).

The primary objective of this work was to evaluate the influence of environmental conditions on the germination of different lots of $M$. urundeuva. Thus, different temperatures (simulating thermal stress) and osmotic potentials, obtained with polyethylene glycol - PEG (simulating drought stress) and $\mathrm{NaCl}$ (simulating salt stress), were assessed. The hypothesis tested was that seeds with different physiological qualities respond differently to these environmental stresses. Besides that, thermal and osmotic limits were determined, based on thermal time, hydrotime and halotime models (Bradford, 2002; Seal et al., 2018). The goal was to evaluate the efficiency of those models and describe the germinative behavior of M. urundeuva seeds in adverse conditions. Lastly, current climate data and projections were used to predict how these seeds might germinate in future climate scenarios.

\section{Material and Methods}

\section{Harvest and seed processing}

Diaspores of $M$. urundeuva were collected directly from mother-plants in a partially human-degraded Caatinga area at the municipality of Lagoa Grande, Brazilian state of Pernambuco $\left(8^{\circ} 34^{\prime} 13.1^{\prime \prime} \mathrm{S}, 40^{\circ} 11^{\prime} 02.2^{\prime \prime} \mathrm{W}\right)$. The harvests occurred between August and September of 2010, 2011, 2012, and 2013, from the same population. Seed processing included a manual pre-cleaning, in which diaspores had the wings detached, and branches were removed. Then, a seed blower was used to clean off any remaining dirt (Matias et al., 2014). The diaspores were packed in cloth bags (permeable) and placed inside a cold chamber $\left(\mathrm{T}=10{ }^{\circ} \mathrm{C}\right.$, $\mathrm{RH}=45 \%$ ), where they remained until January 2014. The water content of $M$. urundeuva seed lots at the beginning of the germination experiments was of $9.47 ; 9.36 ; 10.02$; and $10.04 \%$ for the lots harvested in 2010, 2011, 2012, and 2013, respectively (Brasil, 2009). 


\section{Previous and future climate data}

Monthly data on air temperature and precipitation of the different harvests were gathered at the Automated Agrometeorological Station of Bebedouro, at Embrapa Semiárido, based in Petrolina, state of Pernambuco (09 $09^{\circ}$ S, $40^{\circ} 22^{\prime} \mathrm{W}$ ) within a distance of $64.5 \mathrm{~km}$ from the mother-trees (Figure 1). Historical average data (from 1970 to 2017), concerning the Meteorological Field Station of Caatinga and obtained by the Agro-meteorology Laboratory at Embrapa Semiárido $\left(09^{\circ} 13\right.$ 'S, $40^{\circ} 29^{\prime} \mathrm{W}$ ), were also used. The RCP 8.5 scenario was taken as a forecast, giving an average temperature rise of $3.5^{\circ} \mathrm{C}$ (IPCC, 2014) and a precipitation reduction of 40\% (PBMC, 2013) until 2100.

\section{Germination of seeds at different temperatures and osmotic potentials}

Prior to the germination experiments, the diaspores were submerged in neutral detergent for five minutes. Then, the seeds were extracted by manually removing the exocarp and mesocarp of the diaspores under running water, with the aid of a steel sieve. Next, the seeds were superficially disinfested by immersion in a commercial chlorine solution (bleach) for three minutes, and then they were treated with the fungicide $\operatorname{Captan}^{\circledR}\left(3 \mathrm{~mL} . \mathrm{L}^{-1}\right)$ for another three minutes.

The experimental design was completely randomized, and three replicates of 50 seeds were used in every trial assessing the influence of environmental conditions on the germination of $M$. urundeuva. To evaluate the effect of temperature, a $7 \times 4$ factorial scheme was employed, which corresponded to seven constant temperatures $(10,15,20,25$, 30,35 , and $40^{\circ} \mathrm{C}$ ) and the seed lots from four harvest-years $(2010,2011,2012$, and 2013). The effect of drought was analyzed using an $6 \times 4$ factorial scheme, with six osmotic potentials $(0,-0,2,-0,4,-0,6,-0,7$ e $-0,8 \mathrm{MPa})$ using aqueous solutions of polyethylene glycol- PEG 6000 and the four seed lots. The effect of salinity was analyzed by using an $8 \times 4$ factorial scheme, with eight osmotic potentials obtained from $\mathrm{NaCl}$ solutions $(0,-0.072,-0.144,-0.216,-0.288$, $-0.360,-0.432$, and $-0.504 \mathrm{MPa}$ ) and the four seed lots.

Myracrodruon urundeuva seeds from different lots were sown in acrylic boxes (dimensioned $11 \times 11 \times 3.5 \mathrm{~cm}$ ), containing two blotting paper sheets as substrate. They had been moistened with distilled water or one of the solutions $(\mathrm{NaCl}$ or PEG6000) mentioned above, in a proportion of 2.5 times the dry paper weight (Brasil, 2009). Next, the seeds were incubated for 14 days, in a $12 \mathrm{~h}$ photoperiod, at constant temperatures of 10 to $40{ }^{\circ} \mathrm{C}$ (temperature effect) or $25^{\circ} \mathrm{C}$ (osmotic or salinity effect). Germination was, considered as $1 \mathrm{~mm}$ of primary root visible, and was evaluated $12 \mathrm{~h}$ after setting the experiment,

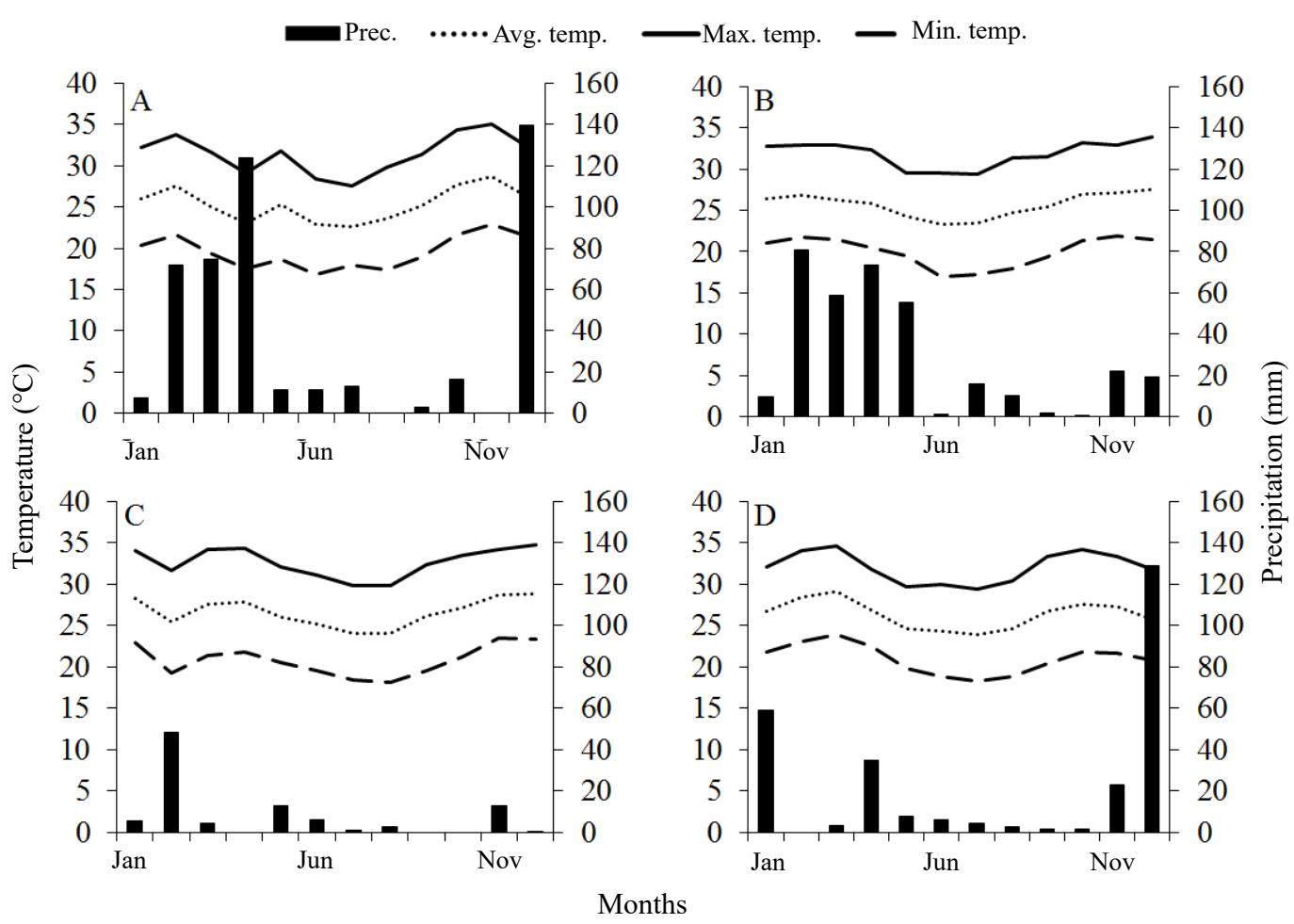

Figure 1. Total precipitation (prec) and average, maximum and minimum air (Avg. temp., Max. temp. and Min. temp., respectively) in 2010 (A), 2011 (B), 2012 (C), and 2013 (D), in the city of Petrolina - PE. 
and then at every hour until its stabilization.

The physiological quality of the seeds was appraised by the final germination percentage (G\%) after 14 days (Brasil, 2013) and by the germination speed index (GSI) (Maguire, 1962). The data were subject to analysis of variance with the software Assistat, and then submitted to regression analysis (Silva and Azevedo, 2016).

\section{Obtaining thermal time and hydrotime of seeds}

The cumulative germination was plotted as a function of time for each temperature, and then fitted to sigmoidal Boltzmann curves. The germination rate (GR) was calculated as a reciprocal function of the time necessary to reach $50 \%$ germination $\left(1 / t_{50}\right)$ (Covell et al., 1986). By knowing the GR values associated with each temperature, linear regression analysis was performed. They allowed the calculation of the interception on the $\mathrm{x}$-axis, at the sub- and supra-optimum temperature ranges, generating estimates for the base temperature $\left(\mathrm{T}_{\mathrm{b}}\right)$ and ceiling temperature $\left(\mathrm{T}_{\mathrm{c}}\right)$. Below and above these values, respectively, the GR is equal to zero (Covell et al., 1986; Ellis et al., 1986). The interception between the two regression lines at the sub- and supra-temperatures was used to estimate the optimum temperature $\left(\mathrm{T}_{\mathrm{o}}\right)$ (Hardegree, 2006).

The thermal time of the population that germinated at sub-optimum temperatures $\left(\theta_{\text {Tsub }}\right)$ and that of the population that germinated at supra-optimum $\left(\theta_{\text {Tsupra }}\right)$ temperatures were estimated using the following equations:

$$
\begin{array}{ll}
\theta_{\text {Tsub }}=\left(\mathrm{T}-\mathrm{T}_{\mathrm{b}}\right) \mathrm{t} & \text { (equation 1) } \\
\theta_{\text {Tsupra }}=\left(\mathrm{T}_{\mathrm{c}}-\mathrm{T}\right) \mathrm{t} & \text { (equation 2) }
\end{array}
$$

Where $\mathrm{T}$ it the germination temperature; $\mathrm{T}_{\mathrm{b}}$ is the base temperature; $T_{c}$ is the ceiling temperature; and $t$ is the time since the imbibition started (Covell et al., 1986).

The germination percentages corresponding to each osmotic potential $(\psi)$ studied were graphically represented as a function of time. Then, a regression analysis was conducted, as above mentioned, to determine the interception on the $\mathrm{x}$-axis, producing estimates of the base osmotic potential $\left(\psi_{\mathrm{b}}\right)$, below which the GR is null (Gummerson, 1986). Germination responses concerning the osmotic potential were also described according to the hydrotime $\left(\theta_{\mathrm{H}}\right)$ or halotime $\left(\theta_{\mathrm{HNaCl}}\right)$ scale, which was calculated for each osmotic and salt treatment as follows (Gummerson, 1986; Bradford, 2002; Seal et al., 2018):

$$
\left.\theta_{\mathrm{H}} \text { or } \theta_{\mathrm{HNaCl}}=\left(\psi-\psi_{\mathrm{b}}\right) \mathrm{t} \quad \text { (equation } 3\right)
$$

Where $\psi$ is the osmotic potential; $\psi_{\mathrm{b}}$ is the osmotic base potential; and $t$ is the time since imbibition started.

\section{Germination prediction for current and future climate}

Previous climate data and the future RCP 8.5 scenario (IPCC, 2014) were used to calculate the environmental thermal sum and to predict seed germination, by using the parameters $\mathrm{T}_{\mathrm{b}}, \mathrm{T}_{\mathrm{c}}, \mathrm{T}_{\mathrm{o}}, \theta_{\mathrm{T}}, \psi_{\mathrm{b}}$, and $\theta_{\mathrm{H}}$.

The heat sum was calculated weekly (as long as the precipitation of the week in analysis had reached a minimum level of $20 \mathrm{~mm}$ (Santos et al., 2011); according to the following equation:

$$
\text { Heat sum }=\left(\mathrm{T}_{\mathrm{m}}-\mathrm{T}_{\mathrm{b}}\right) \mathrm{t}\left({ }^{\circ} \mathrm{Cd}^{-1}\right) \quad \text { (equation 4) }
$$

Where $T_{m}$ is the average week temperature; $T_{b}$ is the base temperature, below which germination does not occur; and $t$ is the number of days until reaching the thermal time for germination $\left(\theta_{\mathrm{T}}\right)$.

\section{Results and Discussion}

\section{Effects of the environmental stress on germination}

All seed lots of M. urundeuva (2010, 2011, 2012, and 2013) showed germination rates above $70 \%$, by the end of 14 days (336 h) of evaluations at temperatures between 20 to $35^{\circ} \mathrm{C}$ (Figures 2, and $3 \mathrm{~A}$ ). In addition, the beginning of germination was earlier at temperatures from $25{ }^{\circ} \mathrm{C}$ to $35^{\circ} \mathrm{C}$. At this range, $24 \mathrm{~h}$ (lots 2010, 2011, and 2013) to $28 \mathrm{~h}$ (lot 2012) of imbibition were necessary for germination (Figure 2), and the maximum GSI value was obtained (Figure 3B). Seeds of the 2013 lot were more tolerant to high temperature, with a $40 \%$ germination rate, even when subjected to $40^{\circ} \mathrm{C}$. Such an outcome contrasts with the other lots, whose germination remained below $10 \%$ (Figures 2, and $3 \mathrm{~A}$ ). On the other hand, by the end of the evaluation period, the lots harvested in 2010 and 2013 showed germination values of 10 and $11 \%$, respectively, when incubated at $10^{\circ} \mathrm{C}$ (Figures 2, 3A).

The germination rate (GR) has commonly been used to obtain the germination limits of seeds of several species (Covell et al., 1986; Bradford, 2002; Arana et al., 2016; Seal et al., 2017, 2018; Castillo-Lorenzo et al, 2019) due to its linear relation with temperature (Covell et al., 1986). On account of that, the temperature limits, as well as the sub- and supraoptimum thermal times (Figure 4) could be calculated for germination of M. urundeuva seeds. All seed lots germinated at a wide thermal range, with base temperature $\left(\mathrm{T}_{\mathrm{b}}\right)$ below 10 ${ }^{\circ} \mathrm{C}$, except for the 2011 lot $\left(10.3{ }^{\circ} \mathrm{C}\right)$. The values of ceiling temperature $\left(\mathrm{T}_{\mathrm{c}}\right)$ of all seed lots studied were above $40{ }^{\circ} \mathrm{C}$ (Figure 4). About 5\% germination of the 2010 seed ocurred at 10 and $40{ }^{\circ} \mathrm{C}$ (Figure $3 \mathrm{~A}$ ), showing tolerance to a broader temperature range $\left(7.4-50.7^{\circ} \mathrm{C}\right)$ than the other lots (Figure 4), even after four years of storage. 


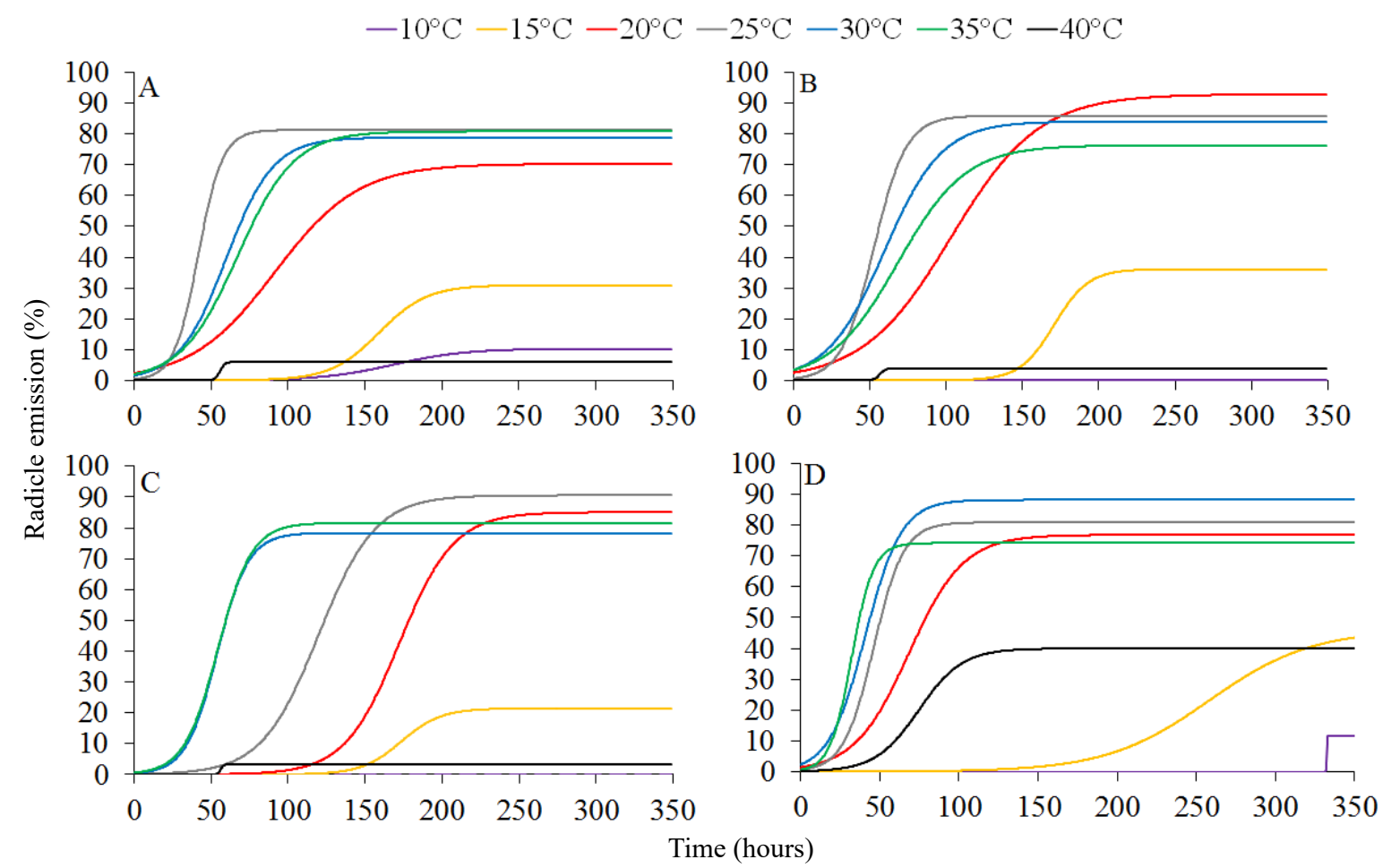

Figure 2. Germination curves (radicle emission percentage) of Myracrodruon urundeuva harvested in 2010 (A), 2011 (B), 2012 (C), and 2013 (D), after non-linear fitting, according to the Boltzmann sigmoidal model, as a function of different temperatures.

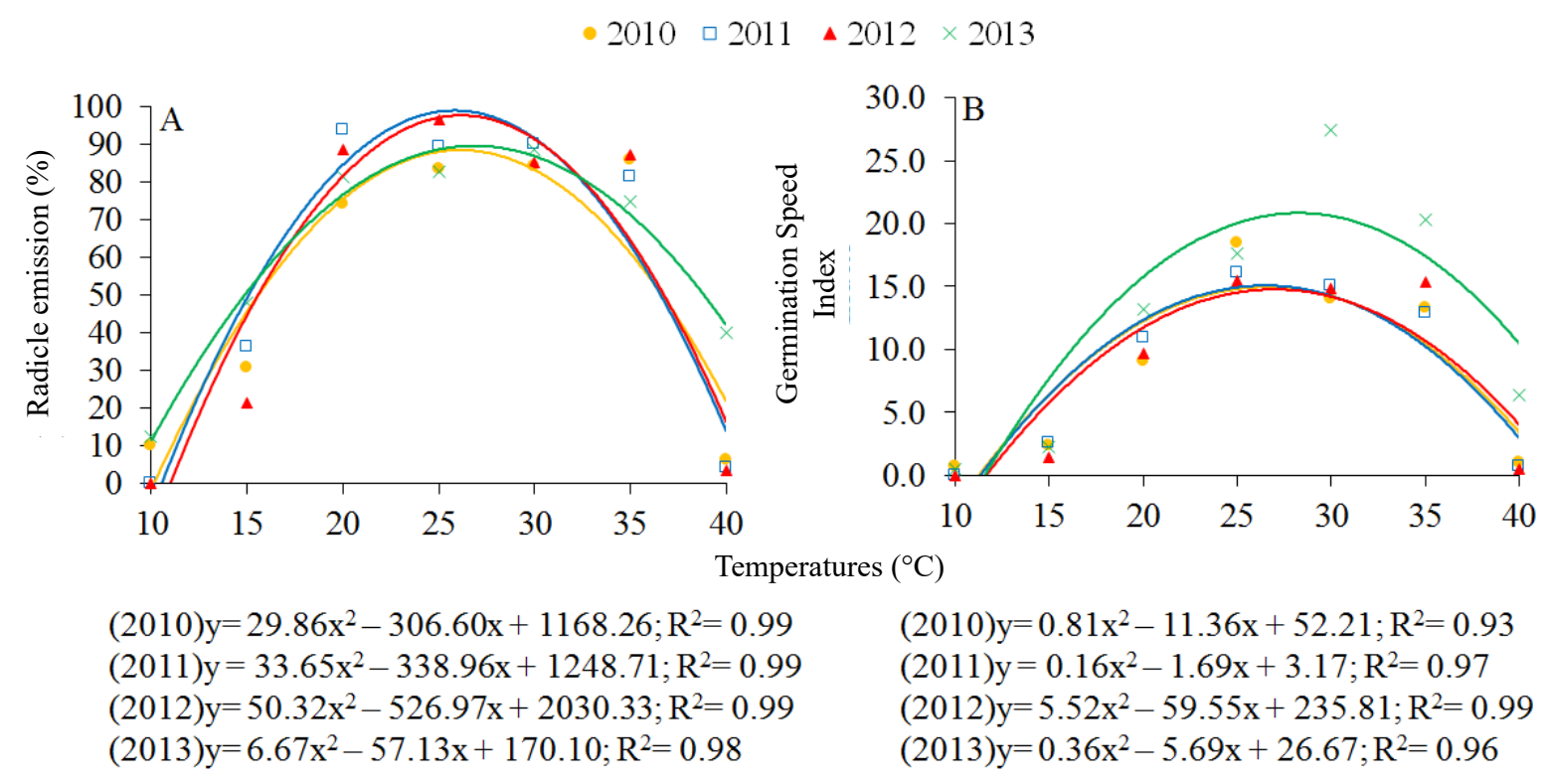

Figure 3. Germination (A) and average speed index (B) of Myracrodruon urundeuva seeds from different lots subjected to different temperatures.

Fresh seeds of M. urundeuva collected in 2007 from the same population, exhibited maximum germination at $25{ }^{\circ} \mathrm{C}$, and no germination at $40{ }^{\circ} \mathrm{C}$ (Virgens et al., 2012), while the seeds from all lots collected between 2010 and 2013 showed some germination at $40{ }^{\circ} \mathrm{C}$, and optimum temperature $\left(\mathrm{T}_{\mathrm{o}}\right.$ ) varied between 26.6 to $34.7^{\circ} \mathrm{C}$ (Figure 3). 
These results indicate that lots from different harvests can respond differently to environmental conditions during the germination stage.
The adequate temperatures to evaluate $M$. urundeuva seeds are known to be $25^{\circ} \mathrm{C}$ or $20-30{ }^{\circ} \mathrm{C}$, based on seeds harvested from regions with milder temperatures than those studied in

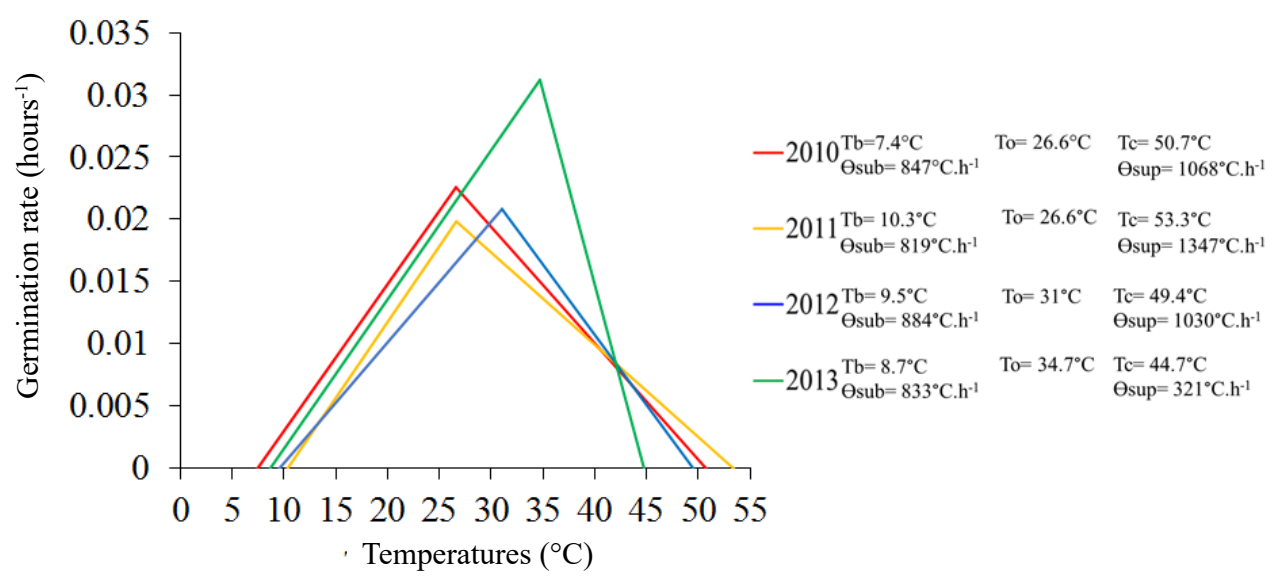

Figure 4. Germination rate (GR), thermal limits and requirements of Myracrodruon urundeuva seeds harvested in 2010, 2011, 2012, and 2013, and subjected to different temperatures. $T_{b}$ and $T_{c}$ correspond to base and ceiling temperatures for germination, respectively (the point on which the regression curves intercept the $\mathrm{x}$-axis); $\mathrm{T}_{\mathrm{o}}$ is the optimum temperature; $\theta_{\text {sub }}$ and $\theta_{\text {supra }}$ correspond respectively to the thermal time of the sub- and supra-optimum temperature ranges, obtained by the reciprocal function of the regression curve angle.

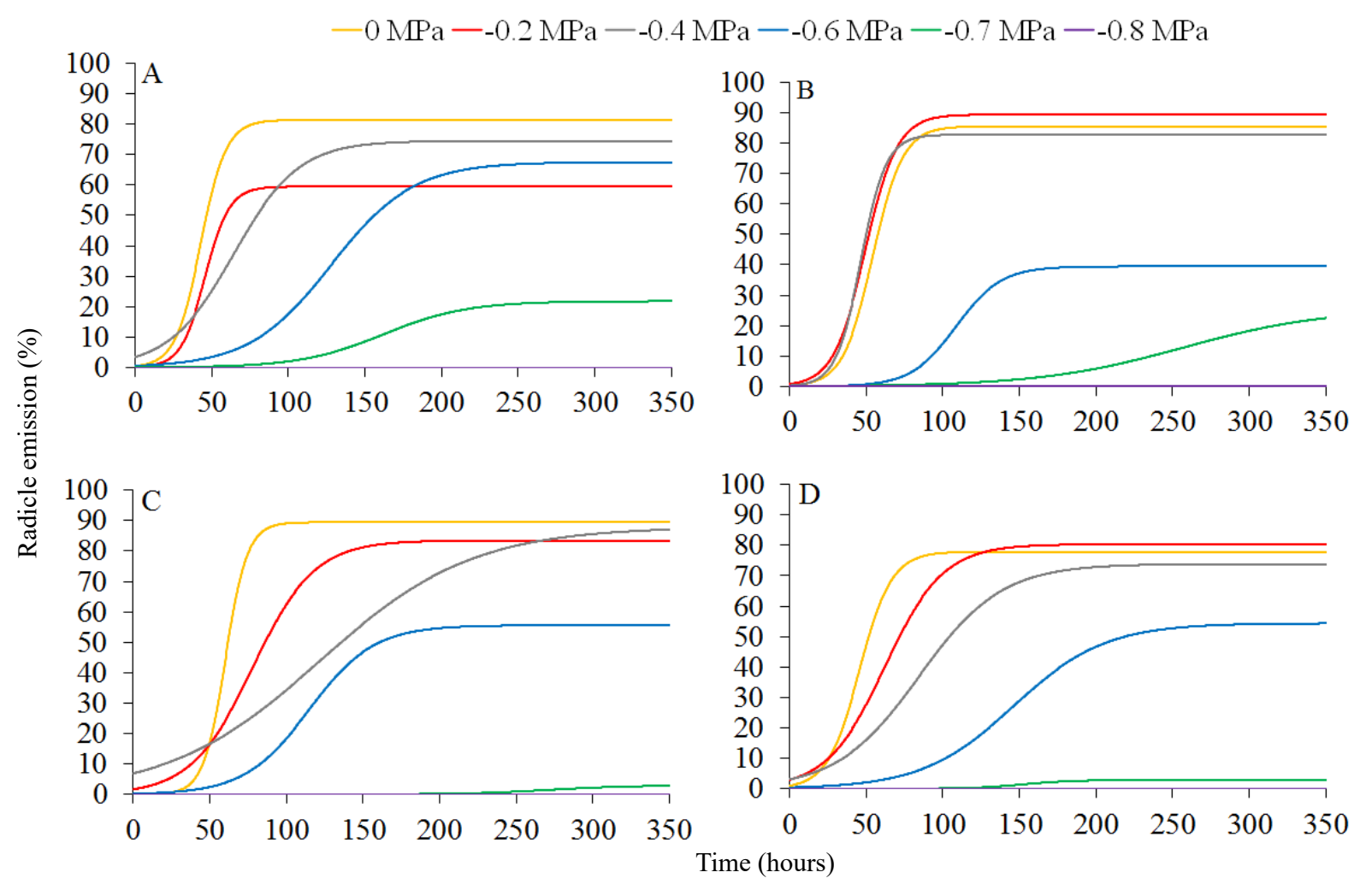

Figure 5. Cumulative germination of Myracrodruon urundeuva seeds harvested in 2010 (A), 2011 (B), 2012 (C), and 2013 (D), and fitted according to the Boltzmann sigmoidal model, as a function of different osmotic potentials produced from polyethylene glycol 6000 . 
this work (Brasil, 2013). Such a difference indicates that the surrounding conditions where the mother-plants are found can affect seeds responses to the environment (Bewley et al., 2013).

Germination in all $M$. urundeuva seed lots was gradually reduced as the osmotic potential increased (Figures 5, 6). Seeds of the 2012 lot started to germinate after $28 \mathrm{~h}$ imbibition; while in those of 2011, 2012, and 2013 lots, the process only began after $40 \mathrm{~h}$ of imbibition (Figure 5). By the end of the evaluation period, the maximum germination was verified in all lots when seeds were submitted to up to $-0.4 \mathrm{MPa}$. At $-0.6 \mathrm{MPa}$, seeds of 2010 lot still germinated above $60 \%$ (Figure 6), but at -0.8
$\mathrm{MPa}$, seeds of all lots failed to germinate. Other Caatinga-native species, such as Zizyphus joazeiro (Lima and Torres, 2009), Mimosa ophthalmocentra (Nogueira et al., 2017), Cenostigma pyramidale (sin. Poincianella pyramidalis), and Anadenanthera colubrina (Santos et al., 2016) showed the same behavior regarding water restriction.

The inclination of the regression curves for germination rate showed that the 2010 lot was the most vigorous and tolerant to water restrictions, reaching a base water potential $\left(\psi_{\mathrm{b}}\right)$ of $-1.1 \mathrm{MPa}$ (Figure 7). Seed vigour can be accounted for such a tolerance to negative osmotic potentials, since

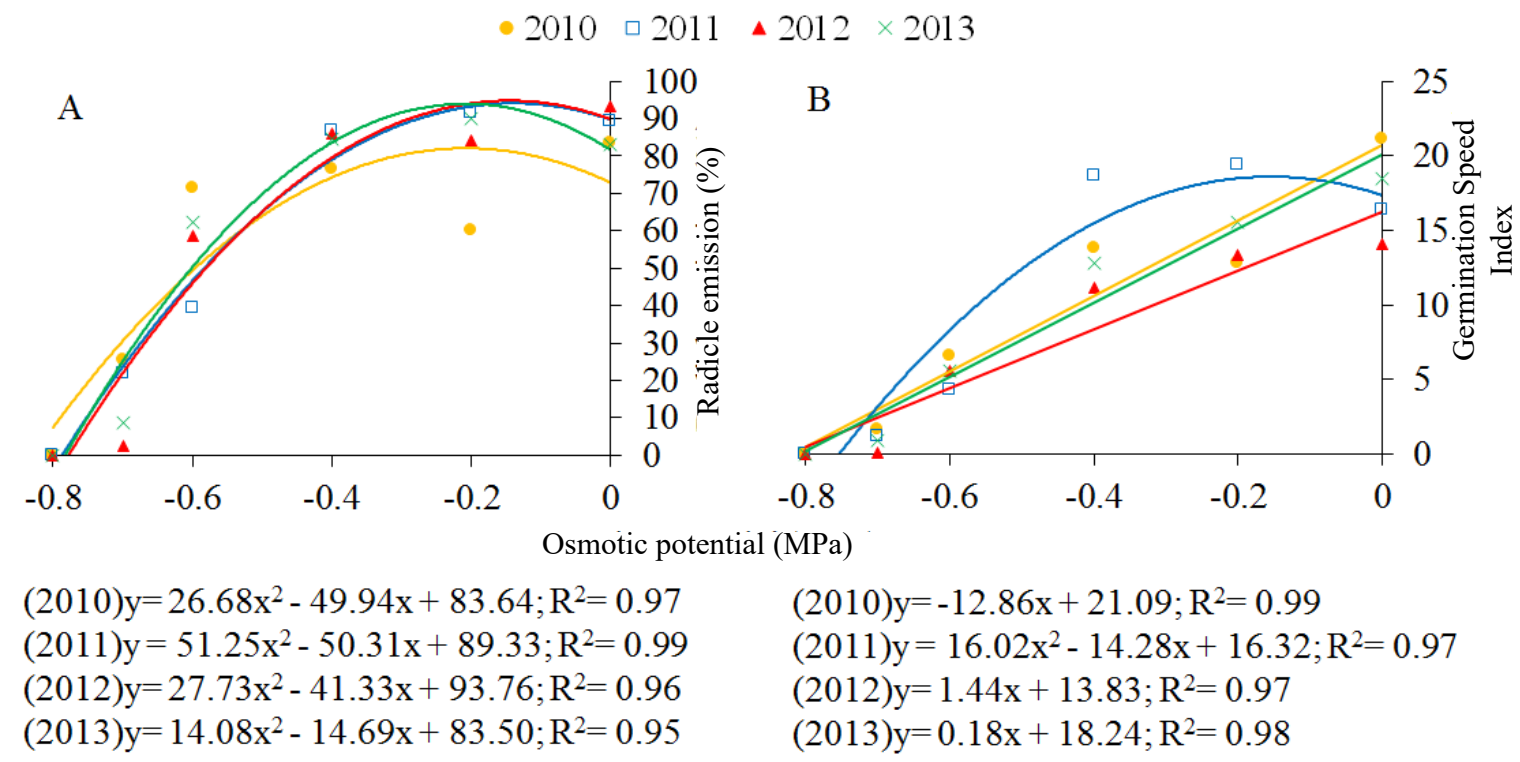

Figure 6. Germination (A) and germination speed index (B) of Myracrodruon urundeuva seeds subjected to water stress by different PEG-6000 osmotic potentials.

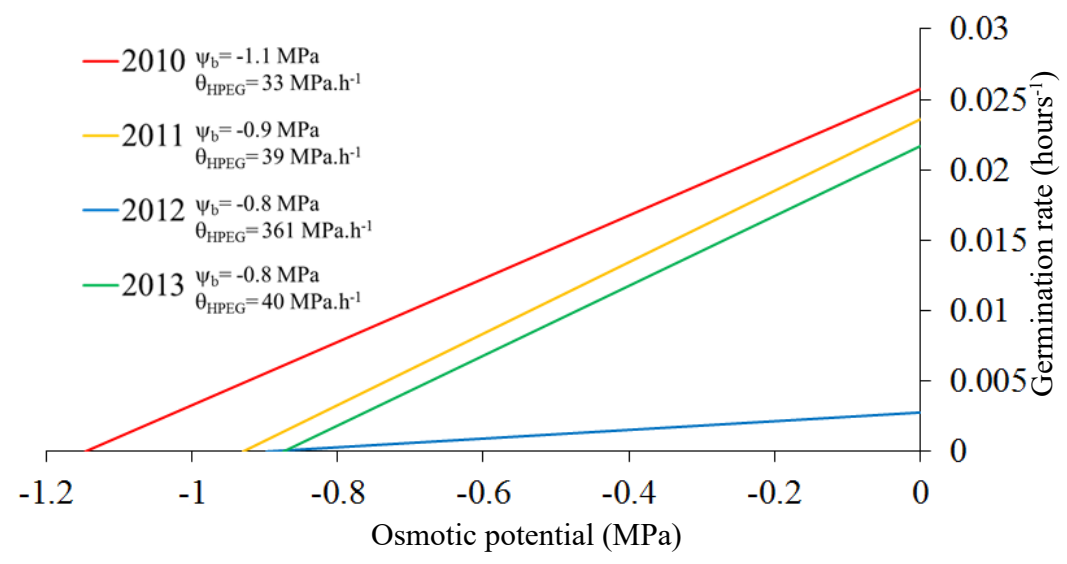

Figure 7. Germination rate, osmotic limits and requirements of Myracrodruon urundeuva seeds harvested in different years and subjected to different osmotic potentials produced from PEG-6000 solutions. $\psi_{\mathrm{b}}$ corresponds to the osmotic base potential for germination (the point on which the regression curves intercept the $\mathrm{x}$-axis); $\theta_{\mathrm{HPEG}}$ corresponds to the hydrotime, obtained by the reciprocal function of the regression curve angle. 
2010 had higher rainfall volume than other harvests, during sprouting (October to June) and flowering of male and female individuals (June to September and July to August, respectively) (Kiill et al., 2010) producing bigger and more vigourous seeds. Studies on the phenophases of M. urundeuva in a semi-arid environment verified that fruitification occurs from August to November (Nunes et al., 2008). Variations in the precipitation levels were observed between different seed harvests (Figure 1), which affected the levels of activity and intensity of each phenophase. Water availability patterns during the phenophases, mostly during flowering and fruitification, is probably the main factor ruling plant reproduction in tropical regions, especially in dry tropical forests (Griz and Machado, 2001).

Seeds of the 2010, 2011, and 2013 harvests showed a germination rate relatively higher than those of the 2012 lot when there was no water restriction involved. Also, even though seeds harvested from 2011-2013 exhibited similar $\psi_{\mathrm{b}}$ $(-0.8$ to $-0.9 \mathrm{MPa})$, the hydrotime $\left(\theta_{\mathrm{HPEG}}\right)$ proved that 2012 seeds required more time to conclude their germination in water restriction. This response is in agreement with the low vigor of the lot, which, in its turn, might be linked to an unusually severe drought, with $65 \%$ less rainfall than the historical average
(Souza et al., 2017; Salimon and Anderson, 2018), mainly during the flowering season (Figure 1).

As for the effect of salinity on M. urundeuva seeds, in general, treatments with osmotic potential above $-0.216 \mathrm{MPa}$ commenced germination more quickly when compared to the other osmotic potentials tested (Figure 8). The maximum germination, by the end of 14 days (336 h) evaluation, was verified in seeds of all lots at osmotic potential above $-0.072 \mathrm{MPa}$. Below $-0.144 \mathrm{MPa}$, as the $\mathrm{NaCl}$ concentration increased, the germination percentage reduced significantly and gradually until its total inhibition at $-0.504 \mathrm{MPa}$ (Figure 9A). The germination speed index (GSI) of seeds of all lots showed higher values when in distilled water, rather than in the other treatments (Figure 9B). This is likely to be the consequence of both ionic toxicity and osmotic stress that can delay germination by affecting physiological and metabolic phenomena in the embryonic tissues (Voigt et al., 2009).

The models generated from M. urundeuva germination rates at different $\mathrm{NaCl}$ concentrations indicated that the 2010, 2011, and 2012 lots were more tolerant to salinity than the 2013 lot (Figure 10). The base osmotic potential $\left(\psi_{\mathrm{b}}\right)$ presented values between -0.5 to $-0.7 \mathrm{MPa}$ for the saline solutions assessed (Figure 10). Also, the reduction in osmotic

$-0 \mathrm{MPa}--0.072 \mathrm{MPa}--0.144 \mathrm{MPa}-0.216 \mathrm{MPa}-0.288 \mathrm{MPa}-0.36 \mathrm{MPa}--0.432-0.504 \mathrm{MPa}$
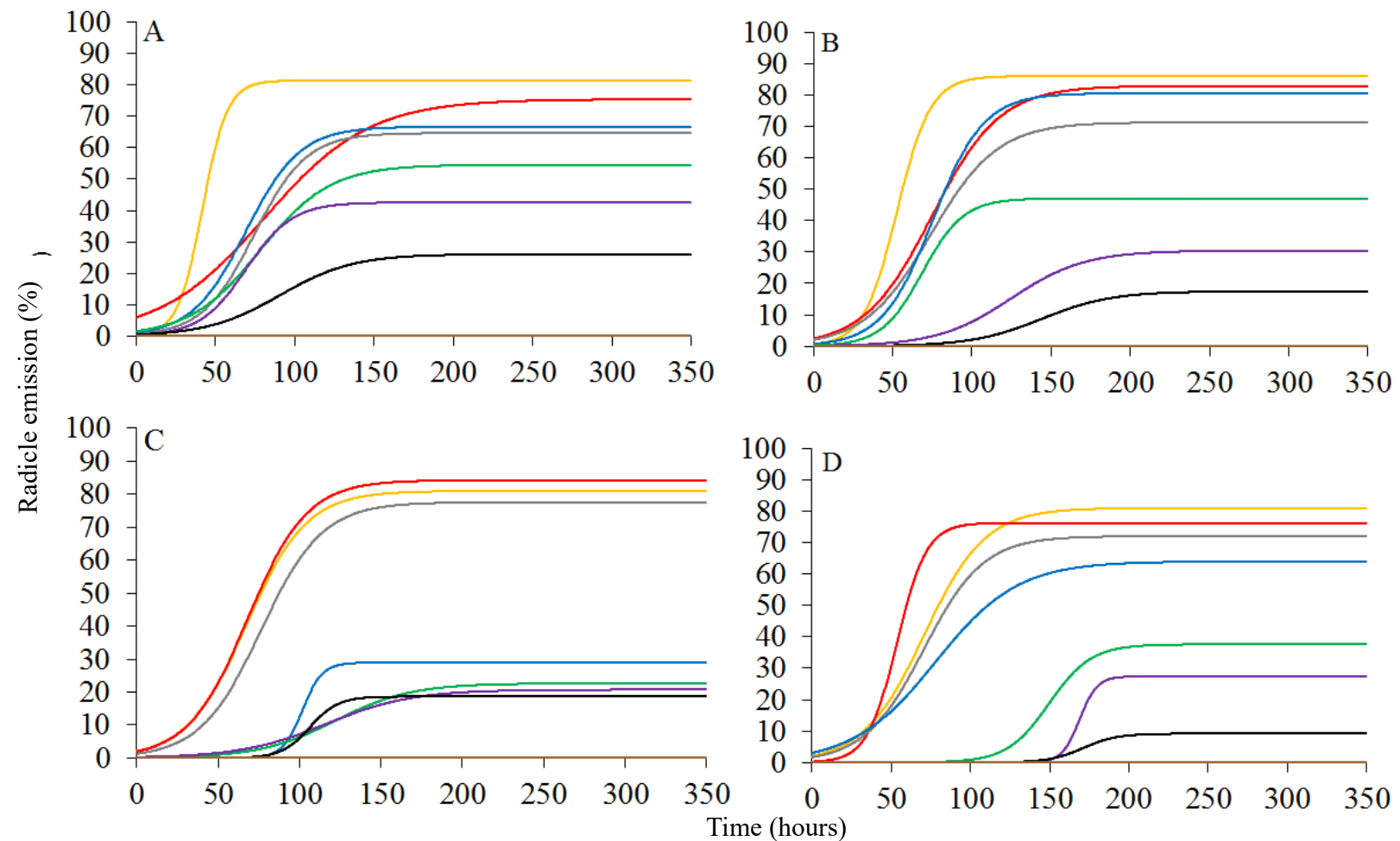

Figure 8. Cumulative germination of Myracrodruon urundeuva seeds harvested in 2010 (A), 2011 (B), 2012 (C), and 2013 (D), and fitted according to the Boltzmann sigmoidal model, as a function of different osmotic potentials obtained with $\mathrm{NaCl}$. 
potential induced by $\mathrm{NaCl}$ had a more detrimental effect on the germination rate than that produced by PEG6000 (Figures 8 and 10). This fact might be the outcome of the $\mathrm{Na}^{+}$buildup, which alters the ionic equilibrium and the availability of mineral nutrients, thus decreasing the cellular division and embryonic development (Moss and Hoffman, 1977). The values of halo-time $\left(\theta_{\mathrm{HNaCl}}\right)$ were also different among the studied lots, and the 2012 lot required more time to complete germination in saline conditions (Figure 10).
The ability to germinate under extreme conditions allows the geographical and temporal distribution of a species, therefore optimizing its survival (Oliveira et al., 2017). So, the success of a species in heterogeneous environments relies on its plasticity (Lima et al., 2010). This capacity was evidenced in the present study by evaluating lots of M. urundeuva at different environmental conditions. The responses displayed by this species are associated with its diverse strategies to adapt to its surroundings (Guedes et al., 2013).

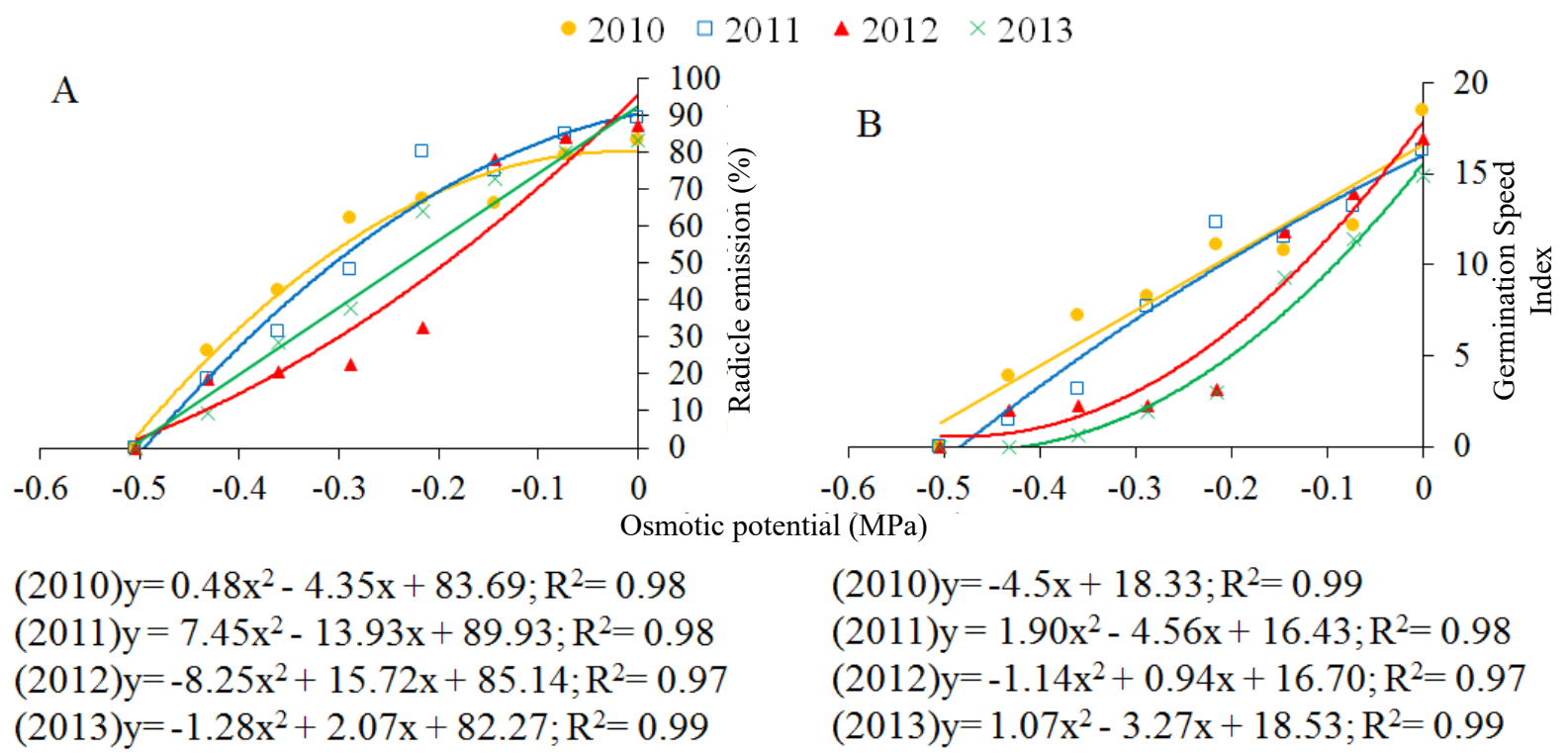

Figure 9. Germination (A) and germination speed index (B) of Myracrodruon urundeuva seeds subjected to salt stress at different $\mathrm{NaCl}$ osmotic potentials.

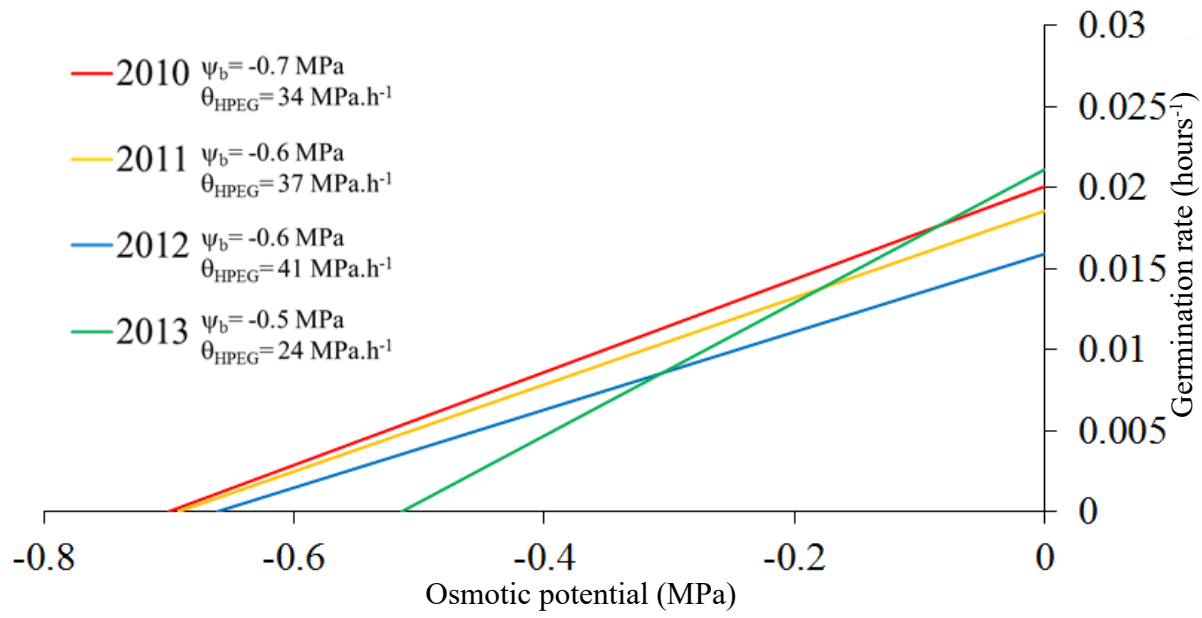

Figure 10. Germination rate, osmotic limits and requirements of Myracrodruon urundeuva seeds harvested in different years, and subjected to different osmotic potentials produced with $\mathrm{NaCl}$ solutions. $\psi_{\mathrm{b}}$ corresponds to the osmotic base potential for germination (the point on which the regression curves intercept the $\mathrm{x}$-axis); $\theta_{\mathrm{HNaCl}}$ corresponds to the hydrotime, obtained by the reciprocal function of the regression curve angle. 


\section{Predictions for germination in future climate conditions}

The heat sum for seed germination was estimated based on the climate data and thermal threshold parameters (equation 4). However, only weeks in which the precipitation surpassed a minimum of $20 \mathrm{~mm}$ were taken into account, because this is the ideal rainfall volume to maintain the Caatinga soil moisture at adequate levels for germination for one week (Santos et al., 2011). For the current climate, the heat sum for germinating seeds of older lots (2010-2012) remained between 35 to $40^{\circ} \mathrm{Cd}^{-1}$, and for seeds of younger lots, it was $25^{\circ} \mathrm{Cd}^{-1}$. For the predictions of future climate conditions, even with more thermal energy existing in the environment, the estimated heat sum was similar to that of the current climate (Figure 11). Also, the average environmental temperature will never surpass the ceiling temperature $\left(T_{c}\right)$ for this species germination (Figure 4), indicating that the future warming will not restrict the germination of these seeds.

On the other hand, a $40 \%$ reduction in the rainfall volume, as predicted by the RCP- 8.5 scenario, will result a decrease in the number of weeks with enough available water for seed germination and initial development of M. urundeuva, thus restraining the recruitment of seedlings. This trend can already be verified in the drought years of 2011 to 2017 (Marengo et al., 2016), as well as in the rainy season between 2016 and 2017, when the precipitation levels remained below $20 \mathrm{~mm}$ per week. In both cases, the emergence of seedlings of M. urundeuva from seed banks was compromised (Silva et al., 2017).

\section{Conclusions}

Myracrodruon urundeuva seeds are tolerant to a broad range of temperatures and osmotic potentials. Nevertheless, such a tolerance depends on the physiological quality of the lots.

Salinity had an effect more detrimental to M. urundeuva seed germination than water restriction.

Climate models allowed identifying M. urundeuva germinative responses in future climate scenarios, which indicate that the lack of rainfall will affect seed germination and initial development, regardless of temperature increase.

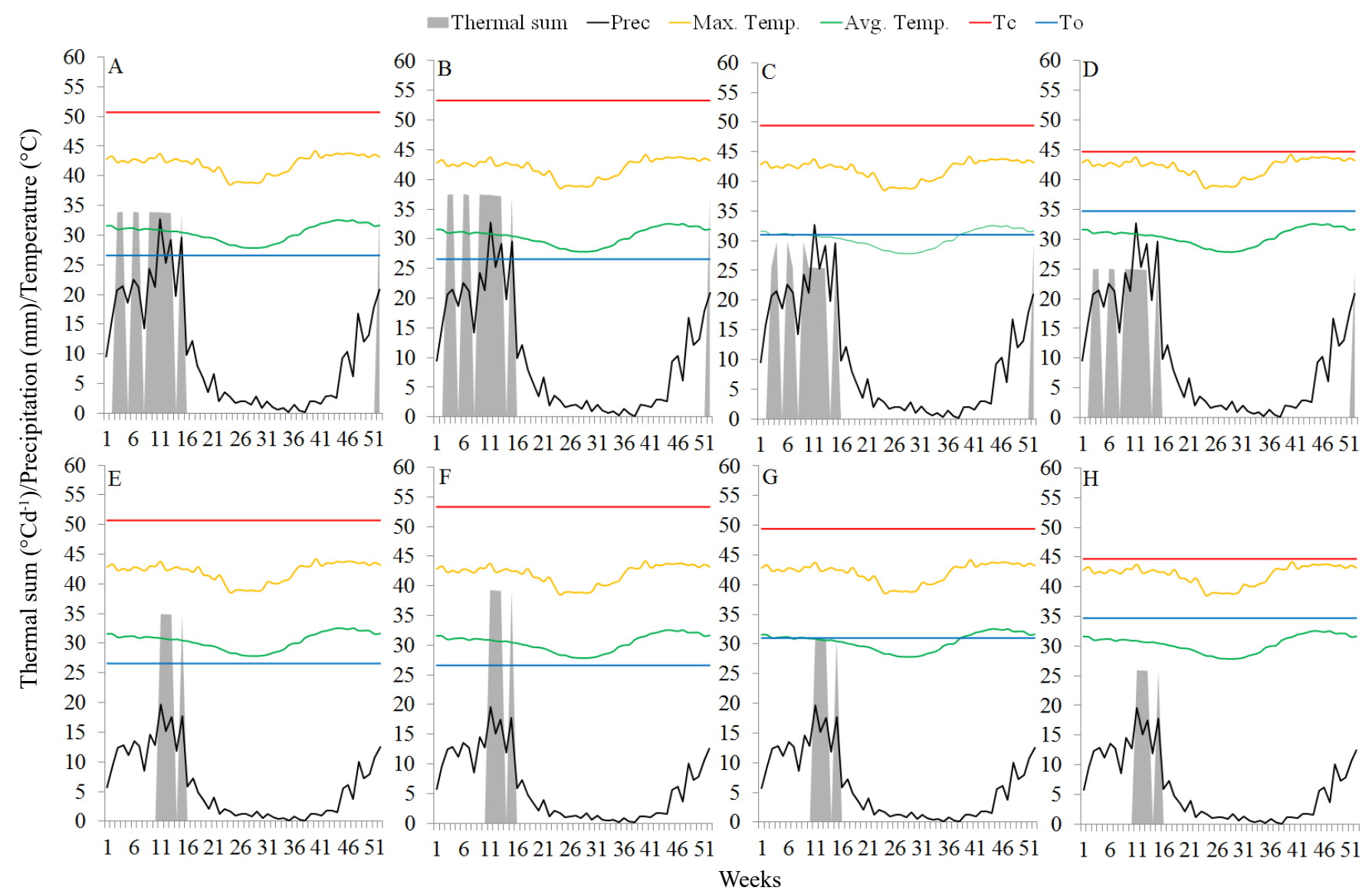

Figure 11. Thermal sum required for the germination events of Myracrodruon urundeuva seeds of the 2010 (A, E), 2011 (B, F), 2012 (C, G), and 2013 (D, H) lots, considering the current climate scenario (A, B, C, and D) and the RCP 8.5 climate prognosis (E, F, G, and H), stated by the Intergovernmental Panel on Climate Change - IPCC/AR5 (IPCC, 2014). 


\section{References}

ARANA, M.V.; GONZALEZ-POLO, M.; MARTINEZ-MEIER, A.; GALLO, L.A.; BENECH-ARNOLD, R.L.; SÁNCHEZ, R.A.; BATLLA, D. Seed dormancy responses to temperature relate to Nothofagus species distribution and determine temporal patterns of germination across altitudes in Patagonia. New Phytologist, v.209, p.507-520, 2016. https://doi:10.1111/nph.13606

BEWLEY, J.D.; BRADFORD, K.J.; HILHORST, K.H.W.M.; NONOGAKI, H. Seeds: Physiology of development germination and dormancy. New York: Springer, 2013. 392p.

BRADFORD, K. Applications of hydrothermal time to quantifying and modeling seed germination and dormancy. Weed Science, v.50, p. 248-260, 2002. https://www.cambridge.org/core/journals/weedscience/article/applications-of-hydrothermal-time-to-quantifyingand-modeling-seed-germination-and-dormancy/4C25559CD 88775 41424A6FFCC8E8F730

BRASIL. Ministério da Agricultura, Pecuária e Abastecimento. Regras para análise de sementes. Ministério da Agricultura, Pecuária e Abastecimento. Secretaria de Defesa Agropecuária. Brasília: MAPA/ACS, 2009. 395p. http://www.agricultura.gov.br/arq_editor/ file/2946_regras_analise_s sementes.pdf

BRASIL. Ministério da Agricultura, Pecuária e Abastecimento. Instruções para análise de sementes florestais. Ministério da Agricultura, Pecuária e Abastecimento. Secretaria de Defesa Agropecuária. Brasília: MAPA/ACS, 2013. 97p. http://www. agricultura.gov.br/assuntos/laboratorios/arquivos-publicacoeslaboratorio/florestal documento pdf-ilovepdf-compressed.pdf

CARLINI, E.A.; DUARTE-ALMEIDA, J.M.; RODRIGUES, E.; TABACH, R. Antiulcer effect of the pepper trees Schinus terebinthifolius Raddi (aroeira-da-praia) and Myracrodruon urundeuva Allemão, Anacardiaceae (aroeira-do-sertão). Revista Brasileira de Farmacognosia, v.20, p.140-146, 2010. http://dx.doi. org/10.1590/S0102-695X2010000200001

CASTILlO-LORENZO, E.; FINCH-SAVAGE, W.E., SEAL, C.E.; PRITCHARD, H.W. Adaptive significance of functional germination traits in crop wild relatives of Brassica. Agricultural and Forest Meteorology, v.264, p.343-350, 2019. doi:10.1016/j. agrformet.2018.10.014

CHAVES, M.M.; FLEXAS, J.; PINHEIRO, C. Photosynthesis under drought and salt stress: regulation mechanisms from whole plant to cell. Annals of Botany, v.103, p.551-560, 2009. https://doi. org/10.1093/aob/men125

CNCFlora. Centro Nacional de Conservação da Flora. Myracrodruon urundeuva in Lista Vermelha da flora brasileira versão 2012.2. http://cncflora.jbrj.gov.br/portal/pt-br/profile/Myracrodruon $\% 20$ urundeuva Accessed on february $17^{\text {th }}, 2018$.

COVELL, S.; ELLIS, R.H.; ROBERTS, E.H.; SUMMERFIELD, R.J. The influence of temperature on seed germination rate in grain legumes I. A comparison of chickpea, lentil, soybean and cowpea at constant temperatures. Journal of Experimental Botany, v.37, p.705715, 1986. https://doi.org/10.1093/jxb/37.5.705

ELLIS, R.H.; COVELL, S.; ROBERTS, E.H.; SUMMERFIELD, R.J. The influence of temperature on seed germination rate in grain legumes. II. Intraspecific variation in chickpea (Cicer arietinum L.) at constant temperatures. Journal of Experimental Botany, v. 37, p. 1503-1515, 1986.
FLORES, A.V.; BORGES, E.E.L.; GUIMARÃES, V.M.; GONÇALVES, J.F.C.; ATAÍDE, C.M.; BARROS, D.P. Atividade enzimática durante a germinação de sementes de Melanoxylon brauna Schott sob diferentes temperaturas. Cerne, v.20, n.2, p.401-408, 2014. http://www.scielo.br/scielo.php?pid=S0104-77602014000300009

FREITAS, A.R.; LOPES, J.C.; MATHEUS, M.T.; MENGARDA, L.H.G.; VENANCIO, L.P.; CALDEIRA, M.V.W. Superação da dormência de sementes de jatobá. Pesquisa Florestal Brasileira, v.33, p.01-05, 2013. https://doi104336/2013.pfb.33.73.350

GONDIM, T.M.S.; CAVALCANTE, L.F.; BELTRAO, N.E.M. Aquecimento global: salinidade e consequências no comportamento vegetal. Revista Brasileira de Oleaginosas e Fibrosas, v.14, n.1, p.3754, 2010. https://www.alice.cnptia.embrapa.br/bitstream/doc/862856/1/ RBOF143754.pdf

GRIZ, L.M.S.; MACHADO, I.C.S. Fruiting phenology and seed dispersal syndromes in caatinga, a tropical dry forest in the northeast of Brazil. Journal of Tropical Ecology, v.17, p.303-321, 2001. https:// sci-hub.tw/10.1017/S0266467401001201

GUEDES, R.S.; ALVES, E.U.; GONÇALVES, E.P.; COLARES, P.N.Q.; MEDEIROS, M.S.; VIANA, J.S. Germinação e vigor de sementes de Myracrodruon urundeuva Allemão em diferentes substratos e temperaturas. Revista Árvore, v.35, n.5, p.975-982, 2011. http://www.scielo.br/scielo.php?pid=S0100-67622011000600003

GUEDES, R.S.; ALVES, E.U.; VIANA, J.S.; GONÇALVES, E.P.; LIMA, C.R.; SANTOS, S.R.N. Germinação e vigor de sementes de Apeiba tibourbou submetidas ao estresse hídrico e diferentes temperaturas. Ciência Florestal, v.23, n.1, p.45-53, 2013. http://www.scielo.br/scielo. php?pid=S1980-50982013000100045\&script $=$ sci_abstract\&tlng $=$ pt

GUMMERSON, R.J. The effect of constant temperatures and osmotic potentials on the germination of sugar beet. Journal of Experimental Botany, v.37, n.6, p.729-741, 1986. https://doi. org/10.1093/jxb/37.6.729

HARDEGREE, S.P. Predicting germination response to temperature. I. Cardinal-temperature Models and Subpopulation-specific Regression. Annals of Botany, v.97, p.1115-1125, 2006. https://academic.oup.com/ aob/article/97/6/1115/207352

IPCC. Climate Change 2014: Synthesis Report. Contribution of Working Groups I, II and III to the Fifth Assessment Report of the Intergovernmental Panel on Climate Change (eds Core Writing Team, R. K. Pachauri, L. A. Meyer), IPCC, Geneva, 2014. 151p.

KIILL, L.H.P.; MARTINS, C.; SILVA, P. Biologia reprodutiva de duas espécies de Anacardiaceae da caatinga ameaçadas de extinção. In: MOURA, A.N.; ARAÚJO, E.L.; ALBUQUERQUE, U.P. (eds) Biodiversidade, potencial econômico e processos ecofisiológicos em ecossistemas nordestinos. Embrapa Semiárido, 2010. p.305-332.

KNOWLES, N.; CAYAN, D. Potential effects of global warming on the Sacramento/San Joaquin watersheds and the San Francisco estuary. Geophysical Research Letters, v.29, n.18, p. 38-1-38-4, 2002. https:// agupubs.onlinelibrary.wiley.com/doi/epdf/10.1029/2001GL014339

LIMA, A.L.S.; ZANELLA, F.; CASTRO, L.D.M. Crescimento de Hymenaea courbaril L. var. stilbocarpa (Hayne) Lee et Lang e Enterolobium contortisiliquum (Vell.) Morong (Leguminosae) sob diferentes níveis de sombreamento. Acta Amazônica, v.40, n.1, p.43-48, 2010. http://www.scielo.br/scielo.php?script=sci arttext\&pid=S0044-59672010000100006 
LIMA, B.; TORRES, S. Estresses hídrico e salino na germinação de sementes de Zizyphus joazeiro Mart. (Rhamnaceae). Revista Caatinga, v.22, n.4, p. 93-99, 2009. https://www.redalyc.org/ $\mathrm{html} / 2371 / 237116334009 /$

MAGUIRE, J.D. Speed of germination aid in selection and evaluation for seedling and vigour. Crop Science, v.2,n.1, p.176-177, 1962. https:// dl.sciencesocieties.org/publications/cs/abstracts/2/2/CS0020020176

MARAGHNI, M.; GORAI, M.; NEFFATI, M. Seed germination at different temperatures and water stress levels, and seedling emergence from different depths of Ziziphus lotus. South African Journal of Botany, v.76, n.3, p.453-459, 2010. https://www. sciencedirect.com/science/article/pii/S0254629910001134

MARENGO, J.A.; CUNHA, A.P.; ALVES, L.M. A seca de 2012-15 no semiárido do Nordeste do Brasil no contexto histórico. Climanálise, v.3, p.1-6, 2016. http://climanalise.cptec.inpe.br/ rclimanl/revista/ pdf/30anos/marengoetal.pdf

MATIAS, J.R.; OLIVEIRA, G.M.; DANTAS, B.F. Colheita e beneficiamento de algumas espécies da Caatinga. Informativo ABRATES, v.24, n.3, p.23-27, 2014. https://www.alice.cnptia.embrapa. br/alice/bitstream/doc/1011665/1/Barbara2014.pdf

MOSS, D.N.; HOFFMAN, G.J. Analysis of crop salt tolerance data. In: SHAIN, I.; SHALHEVET, J. Soil salinity under irrigation: process and management. Berlin: Ecological, 1977. p.258-271.

NOGUEIRA, N.W.; TORRES, S.B.; FREITAS, R.M.O.; CASTRO, T.H.S.; SÁ, F.V.S. 'Jurema-de-embira' seed germination under water stress and at different temperatures. Revista Brasileira de Engenharia Agrícola e Ambiental, v.21, n.4, p.244-248, 2017. http://www.scielo. $\mathrm{br} / \mathrm{pdf} / \mathrm{rbeaa} / \mathrm{v} 21 \mathrm{n} 4 / 1415-4366-$ rbeaa-21-04-0244.pdf

NUNES, Y.R.F.; FAGUNDES, M.; ALMEIDA, H.S.; VELOSO, M.D.M. Aspectos ecológicos da aroeira (Myracrodruon urundeuva Allemão - Anacardiaceae): fenologia e germinação de sementes. Revista Árvore, v.32, n.2, p.233-243, 2008. http://www.scielo. $\mathrm{br} / \mathrm{scielo}$.php? pid $=\mathrm{S} 0100-67622008000200006 \& \mathrm{script}=\mathrm{sci}$ abstract\&tlng=pt

OLIVEIRA, A.K.M.; SOUZA, J.S.; CARVALHO, J.M.B.; OJEDA, P.T.A. Temperatura e substrato na germinação de sementes e no crescimento inicial de plântulas de Sapindus saponaria (Sapindaceae). Gaia Scientia, v.11, p.131-143, 2017. http://trabalhos. congrega.urcamp.edu.br/index.php/jpgp/article/view/961/987

PBMC. Contribuição do Grupo de Trabalho 1 ao Primeiro Relatório de Avaliação Nacional do Painel Brasileiro de Mudanças Climáticas. Sumário Executivo GT1. PBMC: Rio de Janeiro, Brasil, 2013. 24 p.

SALIMON, C.; ANDERSON, L. How strong is the relationship between rainfall variability and caatinga productivity? A case study under a changing climate. Anais da Academia Brasileira de Ciências, v.90, p. 2121-2127, 2018. http://www.scielo.br/scielo.php?script=sci_ arttext\&pid=S0001-37652018000502121\&lng=en\&tlng=en

SANTOS, T.E.M.; MONTENEGRO, A.A.A.; SILVA, D.D. Umidade do solo no semiárido pernambucano usando-se reflectometria no domínio do tempo (TDR). Revista Brasileira de Engenharia Agrícola e Ambiental, v.15, n.7, p.670-679, 2011. https://doi.org/10.1590/ S1415-43662011000700004
SANTOS, C.A.; SILVA, N.V.; WALTER, L.S.; SILVA, E.C.A.; NOGUEIRA, R.J.M.C. Germinação de sementes de duas espécies da Caatinga sob deficit hídrico e salinidade. Pesquisa Florestal Brasileira, v.36, p.219-224, 2016. https://pfb.cnpf.embrapa.br/pfb/ index.php/pfb/article/view/1017/512

SEAL, C.E.; BARWELL, L.J.; FLOWERS, T.J.; MERRETT WADE, E.; PRITCHARD, H.W. Seed germination niche of the halophyte Suaeda maritima to combined salinity and temperature is characterised by a halothermal time model. Environmental and Experimental Botany, v.155, p.177-184, 2018. doi:10.1016/j.envexpbot.2018.06.035

SEAL, C.E.; DAWS, M.I.; FLORES, J.; ORTEGA-BAES, P.; GALÍNDEZ, G.; LEÓN-LOBOS, P.; SANDOVAL, A.; STUVA, A.C.; BULLÓN, N.R.; DÁVILA-ARANDA, P.; ORDOÑEZSALANUEVA， C.A.; YÁÑEZ-ESPINOSA， L.; ULIAN， T.; AMOSSO, C.; ZUBANI, L.; BILBAO, A.T.; PRITCHARD, H.W. Thermal buffering capacity of the germination phenotype across the environmental envelope of the Cactaceae. Global Change Biology, v.23, p.5309-5317, 2017. https:// doi.org/10.1111/gcb.13796

SILVA, F.A.S.; AZEVEDO, C.A.V. The Assistat Software Version 7.7 and its use in the analysis of experimental data. African Journal of Agricultural Research, v.11, p.3733-3740, 2016. https://doi. org/10.5897/AJAR2016.11522

SILVA, F.F.S.; OLIVEIRA, G.M.; ARAÚJO, M.N.; ANGELOTTI, F.; MOURA, M.S.B.; DANTAS, B.F. Rainfall events, high $\mathrm{CO}_{2}$ concentration and germination seeds of Caatinga. Journal of Environmental Analysis and Progress, v.2, n.3, p.258-265, 2017. https://doi.org/10.24221/jeap.2.3.2017.1453.258-265

SOUZA, L.S.B.; MOURA, M.S.B.; SEDIYAMA, G.C.; SILVA, T.G.F. Carbon exchange in a caatinga area during an unusually drought year. Agrometeoros, v.25, n.1, p.37-45, 2017. http://seer.sct. embrapa.br/index.php/agrometeoros/article/view/26265/13855

VIRGENS, I.O.; CASTRO, R.D.; FERNANDEZ, L.G.; PELACANI, C.R. Comportamento Fisiológico de sementes de Myracrodruon urundeuva Fr. All. (Anacardiaceae) submetidas a fatores abióticos. Ciência Florestal, v.22, p.681-692, 2012. http://www.scielo.br/ scielo.php?pid=S1980-50982012000400681

VIVIAN, R.; SILVA, A.A.; GIMENES, J.M.; FAGAN, E.B.; RUIZ, S.T.; LABONIA, V. Dormência em sementes de plantas daninhas como mecanismo de sobrevivência - Breve revisão. Planta Daninha, v.26, n.3, p.695-706, 2008. http://www.scielo.br/scielo.php?pid $=\mathrm{S} 0100-83582008000300026$

VOIGT, E.L.; ALMEIDA, T.D.; CHAGÁSICOS, R.M.; PONTE, L.F.A.; VIÉGAS, R.A.; SILVEIRA, J.A.G. Source-sink regulation of cotyledonary reserve mobilization during cashew (Anacardium occidentale) seedling establishment under $\mathrm{NaCl}$ salinity. Journal of Plant Physiology, v.166, p.80-89, 2009. http://editora.iftm.edu.br/ index.php/sepit/article/view/319/172 